\title{
Service Learning at an HSI: A Preliminary Analysis
}

Andrew Smith, $\mathrm{PhD}$

University of Texas Rio Grande Valley 


\begin{abstract}
An emerging body of literature seeks to design, implement, and analyze best practices in service learning at undergraduate universities. What scholars have not examined as well is service learning at Hispanic-Serving Institutions (HSI's). Given that students at such universities are in unique learning environments, there is a question of how well standard practices in service learning apply to HSI's. In my paper, I will present my analysis of 2 semesters' worth of servicelearning requirements in an Introduction to American Politics course at an HSI in Texas. Using the feedback provided by the students on the final course evaluations, I conclude that the current pedagogy applies reasonably well to HSI's, but there are certain areas in which pedagogy should be adjusted to reflect the unique aspects of HSI's, such as accounting for the socioeconomic needs of HSI students.
\end{abstract}


Keywords: education, service-learning, civics 


\section{Introduction}

Service learning - defined herein as an active learning pedagogy "whereby course learning outcomes are linked with community service in a way that enhances comprehension of course content while leading to transformative change in student awareness, critical thinking, personal values, and civic responsibility, as well as empowerment of and reciprocity with community partners" (Barnett 2018) - has become a topic of much interest in political science since at least the late 1990s. The decline in political participation among younger Americans (Putnam 2001; Barnett 2018), a disinterest in the political fate of the local community (Hepburn, et al 2000), a greater push by universities to give students demonstrable post-graduate work skills (Stolley, et al 2017), and a desire by professors to compose teaching techniques beyond the traditional lecture have led to calls to intersect community engagement and traditional academic coursework. Scholars and practitioners have sought to provide guidance on the best practices and most effective ways to conduct service learning in a college environment, focusing on defining the underlying pedagogy of service learning and its impact (Kezar and Rhoads 2001), best practices in service learning (Bowen 2010; Mayhew and Engberg 2011; etc.) and assessment of service impact among students (Eyler, et al 1997) and the community (Driscoll, et al 1996).

There is a key unit too often left out of the discussion about service-learning pedagogy: how can service-learning pedagogy be adapted to the unique experiences of historically marginalized students? This omission goes beyond the concerns raised by scholars that the current state of service-learning pedagogy can reinforce unequal power structures between service "clients" and volunteers (Vogelgesang 2012; Jones, et al 2013) and between professors and students (Mitchell, et al 2012). The concern here is that most studies heretofore have examined pedagogy from the view of Predominantly-White Institutions (PWI's). To the extent that service-learning research has examined the Hispanic/Latinx communities, it is mostly to address increasing the enrollments of Hispanic/Latinx students in higher education (e.g. Sheil and Rivera 2016). This scholarly omission is problematic for many reasons, including the lower socioeconomic status among students at many non-PWI's and the lack of focus on the emerging Hispanic/Latinx populations. If service learning improves community engagement and political efficacy (Hepburn, et al 2000; Nishishiba, et al 2005; etc.), and the Hispanic/Latinx communities are the fastest-growing demographic groups in the US, then the failure to thoroughly examine service-learning's impact on these students prevents us from better understanding the role of service learning in higher-education political science courses.

This paper seeks to fill in a component of this gap in research by discussing service learning at Hispanic-Serving Institutions (HSI's). I also provide concrete examples of service learning in action at an HSI by presenting results from the implementation of a service-learning course component at an HSI in the Lower Rio Grande Valley in the 2019-2020 academic year. After examining the existing literature and explaining why pedagogy at HSI's needs more examination, I outline the service-learning setup and implementation, how I adjusted the component between the Fall 2019 semester and the Spring 2020 semester, and the final evaluation of the service-learning projects pursued by students. I conclude that many of the existing pedagogical practices in the extant literature apply well to an HSI, but the research herein provides specific ways in which service learning can be adapted to HSI's, as well as 
tangible evidence of the successfulness of these methods. I conclude by explaining where the research into service-learning pedagogy should go from here.

\section{$\underline{\text { Service Learning in Political Science }}$}

The modern emphasis on service learning by political science can be traced back to a 1998 APSA taskforce on civic education, which recommended that the discipline reengage with civic education for the purpose of improving political engagement among young adults and strengthening ties between universities and their communities (Leonard 1999). The use of service learning for the purpose of civic education goes back as far as Dewey's insistence that education should not be divorced from life outside of the academy (Hepburn, et al 2000), but the aforementioned decline in political engagement among new generations of Americans - and the concerns that the emphasis on research in the academy was stymieing efforts to educate students (Leonard 1999) - led to a renewed interest in service learning in political science. Since the APSA taskforce issued its recommendations, scholars have sought to not only reintroduce service learning into the political science curriculum but also establish best practices regarding student assessments and what constitutes "successful" service learning, among other aspects.

The benefits of including service learning in a course's curriculum are legion, so I will only focus on a few. One benefit is the development of skills which are transferable to life after college, such as cognitive skill improvement (Vogelgesang and Astin 2000), and the combatting of knowledge that cannot be applied to new situations (Eyler 2002). For example, Stolley, et al (2017) surveyed students who served at a university-run homeless shelter and found that students reported higher interpersonal skill development (i.e. a better understanding of appropriate interactions with others), better communication skills, and improved leadership and teamwork skills. The students also reported that these skills carried over into their work following graduation.

Another potential benefit of service learning in political science is that it can decrease political polarization. Service learning forces students to encounter groups with whom students are less familiar (Stolley, et al 2017), including groups susceptible to "othering," such as immigrants and AIDS patients (Hepburn, et al 2000; Jones, et al 2013). When service learning is integrated into classroom concepts, service can help students better connect power structures to social conditions and how these conditions can be changed (Stoecker 2016). Similarly, service learning can improve student understanding of, and commitment to, social and racial justice (Vogelgesang and Astin 2000; Waldner, et al 2011) and higher-order cognition regarding complex social problems (Eyler 2002). The caveat here is that service learning must be designed to avoid asymmetry-of-power relationships and reinforcing stereotypes students have about clients (Mitchell, et al 2012; Jones, et al 2013; Stolley, et al 2017), in addition to the need to actively merge classroom theory with service practice and to encourage students to reflect deeply on problems they (likely) have not encountered prior to their service (Eyler 2002).

At the same time that political polarization may decrease, political efficacy may increase if service learning is integrated into a course. Increasing political efficacy is particularly important regarding students coming from lower socioeconomic status backgrounds. Scholars 
going back to Campbell, et al (1960) have demonstrated that those from lower socioeconomic status backgrounds are less likely to believe that their voice makes a difference and are less likely to participate in the political process. Service learning can boost self-concept by actively participating in their community and seeing the tangible results of their efforts (Morgan and Streb 2001; Waldner, et al 2011).

Importance of Understanding Service in Context of HSI

Though the existing literature is invaluable, extant research has little examined HSI's. This is problematic, for several reasons. One is the increase in the number of HSI's, and the increase in the number of students these institutions serve. The number of HSI's have increased from 137 in 1990 to 569 in 2019, and 2.2 million of the 3.3 million Hispanics enrolled in college in 2019-20 attend HSI's. ${ }^{1}$ Hispanics and Latinx are now the $2^{\text {nd }}$-largest category of students at US colleges and universities. ${ }^{2}$ Despite this increase, the extant literature examines service learning at predominantly white institutions (PWI's). While this does not inherently mean that service-learning research focused on PWI's will not apply also to HSI's, the research on pedagogical practices in service learning is incomplete unless there is an account of servicelearning practices at HSI's.

Another important reason to examine HSI's is the correlation between HSI's and the communities in which many HSI's are centered. Students at HSI's - particularly regional universities - are often products of the surrounding community: most of the students at the University of Texas Rio Grande Valley, for example, come from the four counties surrounding the campuses. Combined with the Hispanic/Latinx community's emphasis on family and caring for others (Shetgiri, et al 2009; Ryan and Ream 2016; etc.), the need to build community relationships may already exist among these students. This is invaluable for understanding service-learning pedagogy, because research incorporating this possibility can lead to an adjustment of practices to reflect the students at HSI's.

Another drawback to the exclusion of HSI's in the study of service learning is the risk of a narrow pedagogy. HSI's generally consist of students from lower socioeconomic backgrounds, ${ }^{3}$ students for whom time is a precious commodity. Service-learning projects require a time commitment. Without an understanding of best practices for those students who require full-time or multiple employment, we scholars risk prescribing a set of best practices which apply only to a narrow crop of students. At worst, by not looking at HSI's as an entity distinct from PWI's, we risk ascribing a "pedagogy of whiteness" (Mitchell, et al 2012) to a student population which is historically "outside" the white Anglo learning environment. This marginalizes the unique experiences of Hispanic- and Latinx-Americans and may reduce the likelihood of a lifelong commitment to community service and civic engagement.

\footnotetext{
${ }^{1}$ https://hacuadvocates.net/hacu/abouthsis? 1

2 https://www.insidehighered.com/news/2019/05/23/pew-study-finds-more-poor-students-attending-college

${ }^{3}$ This is somewhat by design: per Title V of the Higher Education Act of 1965, an HSI must enroll a certain number of students who require need-based financial aid https://www2.ed.gov/programs/idueshsi/title5legislation.pdf
} 
A further reason to explore service learning at HSI's is because the potential for service learning to foster political efficacy and engagement is most imperative for HSI's. Most Hispanic/Latinx students are $1^{\text {st }}$-generation college students, ${ }^{4}$ and $1^{\text {st }}$-generation college students are generally underdeveloped in terms of educational and social engagement in high school (Terenzini, et al 1996). These are students for whom civic and political values are even less formed than the values of native-born Anglos. Adjusting service-learning pedagogy to reflect this may ensure the continuation of, or improvement upon, the democratic principles in America (Putnam 2001; Galston 2004), fuse the concepts of civic and political participation (Nishishiba, et al 2005), and forge stronger links between the university institution and the surrounding community.

\section{$\underline{\text { Service Learning at an HSI }}$}

\section{Background of the University of Texas Rio Grande Valley ${ }^{5}$}

It is helpful to the reader to obtain background on the HSI in which I designed and implemented service learning. The University of Texas Rio Grande Valley (UTRGV) is a 4-year, PhD-granting public university. It opened in Fall 2015 out of a merger between two HSI's. In Fall 2019, almost 90\% of the student body identified as Hispanic/Latinx (mostly Hispanic), and almost $58 \%$ of the students identify as women. Most students came from the counties surrounding the university's Edinburg and Brownsville campuses, and - considering that these counties have some of the worst measures of socioeconomic status in the US - most of the students receive some need-based financial aid. UTRGV also has a high number of firstgeneration college students. Typical for $1^{\text {st }}$-generation students (Terenzini, et al 1996; Pike and Kuh 2005), most students work at least one part-time, off-campus job, and most of the students receive at least some financial aid. In comparison to other HSI's in Texas, the student-faculty ratio is high - 27:1, as of Fall 2019. ${ }^{6}$ In contrast, Texas Tech has a 21:1 ratio, and the University of Houston - Downtown has a 20:1 ratio. In the Introduction to American Government and Politics course in which this service learning took place, the number of enrollees was 57 in Fall 2019 and 56 in Spring 2020.

UTRGV is an interesting unit of analysis for reasons beyond the convenience of the sample. Texas requires all undergraduates to complete an Introduction to American Government and Politics course in order to graduate from a state university. This means that the students enrolled in Intro courses come from a variety of backgrounds and are less likely to drop the course, providing a stable sample of service-learning participants. The large class size also provides the opportunity to gather a large number of responses and provide volunteers to a wider variety of organizations. The demographics of the student body allow me to observe the relationship between Hispanic students and a Hispanic community, in order to determine whether there is a different student-community dynamic than those observed in the extant literature. There is also an existing service and engagement structure at the university -

\footnotetext{
${ }^{4}$ https://pnpi.org/first-generation-students/

${ }^{5}$ Unless otherwise noted, all statistics in this section can be found at https://www.utrgv.edu/sair/_files/documents/fall-2019-student-profile.pdf

${ }^{6}$ https://www.utrgv.edu/sair/data-reports/accountabilityreportfy19.pdf
} 
Engagement Zone (EZ) - which could serve as a model for universities seeking to develop their own service-learning programs.

The importance of improving political efficacy among students at UTRGV is important because of the historic lack of political participation in the Lower Rio Grande Valley. Texas is the most difficult state in which to vote, ${ }^{7}$ and for naturalized citizens voter ID obtainment can be more difficult. Combined with the widespread (real and perceived) political corruption in the Lower Rio Grande Valley, students from these communities are likely to have a sense of powerlessness and cynicism about government and the political process. By fostering closer ties with the community and connecting students with service organizations active in the community, there is the possibility of students realizing that there are organized opportunities for change in their community. ${ }^{8}$

\section{Service-Learning Setup - Fall 2019}

Students were required to work at least four hours per month at an approved service organization of their choosing. The existing literature is agnostic on the "appropriate" number of hours students should be required to work, but I chose this number because most of the students at UTRGV are a breadwinner for their household. While I was concerned that such a low number of hours might harm the effectiveness of the students' experience, too many hours would unduly burden working students and make it extraordinarily difficult to complete the service assignment. This is an important aspect of adjusting service-learning pedagogies to HSI's. As previously mentioned, all service-learning pedagogy should be mindful of structural barriers to student participation (Mitchell, et al 2012), but this mindfulness is imperative when working with a lessadvantaged student population.

Although the course took place on the Edinburg campus, students were allowed to volunteer at any organization in the Lower Rio Grande Valley. I placed several restrictions on the types of organizations at which students could complete their hours. Students were allowed to volunteer with non-partisan political organizations (e.g. League of Women Voters), and if they were already volunteering with an organization they could count those hours. However, the students could not volunteer for political campaigns or explicitly partisan political organizations (Texas Rising, Empower Texas, etc.). Students were also not allowed to volunteer with organizations operating solely on campus, and students could not volunteer with religious organizations which operated in a purely proselytizing role. Otherwise, students could volunteer with any organization they wished. I chose this format, rather than assigning students to preselected organizations, because I believed this self-selecting would improve student agency by allowing them to do their own research on organizations and by allowing students to select organizations best matching the student's interests. Students had to complete a profile on the university's student engagement website and sign a university liability waiver.

\footnotetext{
${ }^{7}$ https://newsroom.niu.edu/2020/10/13/how-hard-is-it-to-vote-in-your-state/

${ }^{8}$ Future research will need to examine whether the same processes of post-graduate engagement seen at PWI's (Stolley, et al 2017; Barnett 2018; etc.) also apply to HSI's
} 
I developed a typology of four broad categories of service organizations with whom students participated. The Education and Advocacy category encompasses organizations focused on education needs, such as tutoring and school supply distribution, and organizations focused on advocacy on civic issues, such as violence against women and diabetes prevention. The Environmental category encompasses organizations responsible for community activities to improve ecosystems, such as beach maintenance and trail maintenance. The Community Services category encompasses organizations engaged in targeted charity services, such as pet rescues and community housing. All other organizations were classified as Other, such as a nonprofit community orchestra and city government. As shown in Appendix A, the largest single category of participation was in the Community Services category: $45 \%$ of participants in Fall 2019 and $41 \%$ of participants in Spring 2020 participated in these organizations.

Students had two reflection components of their grade. The first was the reflections that students had to write as they logged their hours for the month. In the Fall 2019 semester, I used a free reflection: students described what they did for their service, but otherwise students were free to write what they wanted. The logic behind doing a free reflection was to increase student writing agency and provide varied perspectives on service (Sturgill and Motley 2014). The second reflection was a final, 3-page paper at the end of the semester. This longer reflection was more structured: students described their role in their organization, provided background about the organization, discussed the challenges facing the organization, and provided concrete examples of how their service impacted their community.

There were two key challenges to establishing service opportunities during the Fall 2019 semester. One was a lack of communication by local organizations: it was not made clear to students before they tried to volunteer that some organizations required background checks or greater time commitments than students could do. Other organizations listed themselves as having volunteer opportunities available, only to inform students who attempted to volunteer that volunteer opportunities were unavailable. These problems should be addressed preemptively by the professor. For example, I noted which organizations students had the most difficulty in working for and excluded them from the list of approved organizations in the Spring 2020 semester.

Another challenge was the usability of the Engagement Zone website in which students logged their hours and reflections. An EZ representative attended the second class of the semester to walk students through setting up an EZ account, signing up with organizations, and logging hours. However, the representatives from EZ were student workers, rather than professional administrators. Consequently, the representatives struggled to explain important concepts to the students, such as how to access the liability forms and how to check on the hours the students worked. While these issues were resolved as the course continued, professors should familiarize themselves with an in-house engagement organization before the term begins, and engagement administrators should make sure their workers are well-trained before allowing them to perform walk-throughs with students.

Changes to Service-Learning Setup - Spring 2020 
I reviewed the student feedback and made several important changes. The most significant was allowing students to volunteer for multiple organizations. As discussed below, giving students the option to fulfill their hours with different groups gave the students greater agency, as the students had more freedom in discovering activities that they enjoyed. Heightening student agency is in keeping with a body of research (e.g. Sturgill and Motley 2014) that indicates students learn best when they have a modicum of control over the assignment. Because students could work with multiple organizations, I increased the required volunteer hours to five per month.

I also shifted to a guided assignment for the reflections the students had to do to log their hours. However, the results were disappointing: student reflections most often consisted of describing their service, with little reflection on how their service related to class concepts or even how their service impacted the organization or community. The guided reflection for Spring 2020 asked students to provide a concrete example of how their service benefited an organization. Examples included accomplishing a project, feedback from a volunteer supervisor, or feedback from clients. I also asked students to include examples linking their service to a community issue, such as how their work in an after-school tutoring program connected to issues of literacy. The logic behind doing a guided reflection was to provide more structure for students, better connect service with the course's goals, and make it easier to compare student experiences and performances in service (Sturgill and Motley 2014). Comparing the Spring 2020 reflection essays to the Fall 2019 essays, the students included more information on how their service was beneficial to their community and included more concrete examples of the effectiveness of their service. For example, one student noted that they "(saw) that there are people who do care about you and the community," while another student described their work with domestic violence victims and how that work not only bettered the community but also affirmed to the student that they should major in social work, in order to advocate for more resources and laws for domestic violence victims.

For the final reflection, students were required to reflect on their volunteer opportunities and discuss how their service impacted their community, and why they believed they had an impact. Although students were encouraged to critique organizations' effectiveness, the focus of the final reflection paper was on the student's role in service. Doing this shifted the focus of the final paper from a focus on organizations to a focus on student participation in service. As discussed below, this shift in focus provoked more positive feedback from students regarding their experiences. Students were also strongly encouraged to relate their service to concepts discussed in class. To facilitate this discussion, I included more material on local governments and community organizations in my curriculum.

\section{Student Feedback on Service Learning}

For both Fall 2019 and Spring 2020, students received two statements on the course evaluations regarding service learning. Students were asked to state their agreement with the statements, on a 1-5 scale. A score of " 1 " indicates that the student strongly disagreed with the statement, and a score of " 5 " indicates that the student strongly agreed with the statement. 
Statement 1: "The service-learning project improved my community engagement skills" Statement 2: "I felt as though my participation in service learning benefited my community"

\section{Fall 2019 Student Feedback on Service Learning}

Appendix B provides the quantitative results of the student evaluations. 38 of 57 students (67\%) responded to both questions. The average student score for Statement 1 was 4.13 (standard deviation of .90), indicating that most students agreed or strongly agreed that the service component improved their community engagement skills. The average student score for Statement 2 was slightly lower -4.08 , with a standard deviation of .89 - but this score still indicates that most students believed their participation in service learning was an asset to their community.

Although the scores are good, I wanted to know about specific improvements that could be made, as well as what the effect of the service hours were on students' work-life balances. I provided an open-ended response question on how the service-learning component could be improved. Appendix C provides the responses to this question, to which 38 students responded, ${ }^{9}$ grouped according to a broad set of categories. A majority of students $(34.2 \%)$ indicated that the assignment did not need to change from its current format. The largest category for suggesting improvements was access to more organizations (16\%), followed by communication and feedback from volunteer organizations $(11 \%) .{ }^{10}$ The required hours did not inconvenience most students: just $10 \%$ of students reported the hours being a significant barrier to completion of their service, and one student suggested significantly increasing the number of service hours required. Students most often suggested that they be allowed to volunteer with organizations not listed in Engagement Zone. The ability to go beyond the Engagement Zone organizations is somewhat limited, for liability reasons, but one method would be to provide more information to local organizations regarding the university and community service, so that more organizations will know that they can partner with the university for volunteer work. In future editions of this course, I will try to establish contact with community organizations not listed in Engagement Zone, educating them on service-learning partnerships with UTRGV and encouraging them to take advantage of those partnerships. It would then be easier to include those organizations as part of the service-learning component of my course. One student's experience should be highlighted, however: the student lives in Mexico, and Engagement Zone does not have partnerships with organizations in that country. This is an issue of which the research regarding HSI's on the US-Mexico border should be cognizant. Some students at border HSI's must cross into the US to go to school, so requiring all service to be done in the US is a barrier to making service effective. Additionally, making service US-centric may lead to a disconnect between Hispanic students and the communities in which they live. Consequently, professors in such areas should make a concerted effort to partner with organizations on the Mexican side of the

\footnotetext{
${ }^{9} 1$ student gave two different recommendations in the Fall 2019 feedback

${ }^{10}$ The category "Other" included responses suggesting that the service component should be made optional or should be dropped altogether.
} 
border. For example, future editions of my course will work with organizations in border cities, such as Matamoros and Reynosa, to establish service partnerships. ${ }^{11}$

Another important consideration manifested on the evaluations is the need for service opportunities to be geographically broad. Students at UTRGV generally do not take all of their classes at a single campus, and UTRGV's status as a commuter school results in students not being centered around the campuses. Consequently, students reported struggling to fulfill their volunteer hours because of a lack of opportunities closer to where they live. The lack of centeredness to campus is not unique to UTRGV. Because of the lower socioeconomic statuses of students at HSI's, most HSI's have a large commuter population, which also means that HSI students are less likely to live on or immediately around their campus (Gasman, et al 2008; Nuñez, et al 2011). This is therefore an area in which service-learning pedagogy should adjust itself to meet the needs of HSI's. For the Spring 2020 semester, I suggested to students more organizations outside of Edinburg, particularly Harlingen and Brownsville (the two largest cities outside of the McAllen-Edinburg area), and future editions of this course will make more efforts to partner with organizations in rural areas.

\section{Spring 2020 Results}

Before discussing the student evaluations for this semester, a caveat should be issued. As with the course itself, the service-learning component was truncated by the COVID-19 pandemic. Although the results in Appendices B and C provide valuable information, only an uninterrupted semester can provide a complete picture as to whether service-learning changes improved the quality of student service and feedback.

Appendix B provides the quantitative results of the student evaluations. 37 of 49 students $(76 \%)$ responded to the questions. The average scores for these questions improved significantly. The average score for Statement 1 was 4.38 (standard deviation of .94), indicating that most students agreed or strongly agreed that the service component improved their community engagement skills. The average student score for Statement 2 was even higher -4.49 , with a standard deviation of .79 - indicating that most students believed their participation in service learning was an asset to their community. Combined with the qualitative feedback reported below, I have preliminary evidence that the changes made for Spring 2020 improved both student agency and the effectiveness of service learning for students.

I used the same two open-ended questions from Fall 2019 to assess how well the servicelearning component did regarding efficacy and a good work-life balance for students, grouped into several broad categories, and these results are reported in Appendix C. Unfortunately, the number of students who responded to the open-ended questions was small: only $62 \%$ of the students who responded to the scaled questions (23) responded to the open-ended questions, and

\footnotetext{
${ }^{11}$ There are drawbacks to this - particularly exposing students to the risk of the cartel violence in Matamoros, Reynosa, and elsewhere - but future research will have to determine the exact benefits and drawbacks to expanding service to include organizations internationally.
} 
the responses were centered on four of the categories. Most students (57\%) reported that no changes needed to be made to the service-learning component.

Of the critical responses, 6 students $(23 \%)$ suggested a wider variety of organizations from which to choose, and in contrast to the fall semester most of these students suggested that service activities should be on campus. This result is interesting, given that no students made this suggestion in the fall semester and given how commuter-centric UTRGV is. Whether this is a one-off complaint, or a consistent concern, will be examined in future editions of this course. However, there are two justifications for why I did not allow students to volunteer with campusonly organizations. One is my assumption about the commuter nature of the UTRGV campus. A commuter campus does not lend itself to campus-centric activities, and I wanted these projects to be accessible to as many students as possible. More importantly, the point of service learning is to gain experiences and interact with communities beyond the college campus. The paradox is that participation in service learning would be improved for underprivileged students if service opportunities were campus-centric, and certainly campus-only organizations do not detract from a meaningful experience for students (e.g. Stolley, et al 2017). However, if the goal of service learning is to foster community engagement and improve political efficacy between students and the off-campus community, then making service learning campus-centric undercuts this goal.

\section{Conclusion}

This paper has provided important insight into how service learning at HSI's is similar to, and different from, service learning at PWI's. When service-learning components are structured to account for the unique experiences of Hispanic students at HSI's, service learning improves student empowerment in their learning, creates a bond between students and the broader community, and enhances political efficacy and engagement among students. The most important thing is for educators to be cognizant of how they structure their service-learning reflections and requirements to meet the needs of HSI students. Without these structural adjustments, service learning at HSI's will be " pure futility and waste"” (Leonard 1999). 
Works Cited for Service Learning at an HSI

Barnett, Leda. 2018. "Service-Learning as a Tool for Increased Political Efficacy and Civic Engagement at a Hispanic-Serving Institution." Citizenship, Social, and Economics Education 17:151-167.

Campbell, Angus; Converse, Philip E.; Miller, Warren E.; and Stokes, Donald E. 1960. The American Voter. New York: Wiley Press.

Driscoll, Amy; Holland, Barbara; Gelmon, Sherril; and Kerrigan, Searra. Fall 1996. "An Assessment Model for Service-Learning: Comprehensive Case Studies of Impact on Faculty, Students, Community, and Institution.” Michigan Journal of Community Service Learning 66-71.

Eyler, Janet; Giles, Dwight E., Jr.; Root, Susan; and Price, Julianne. March 1997. "ServiceLearning and the Development of Expert Citizens." Report from the Annual Meeting of the American Educational Research Association.

Eyler, Janet. 2002. "Reflection: Linking Service and Learning - Linking Students and Communities.” Journal of Social Issues 58:517-534.

Galston, William A. April 2004. "Civic Education and Political Participation”. PS: Political Science and Politics 37:263-266.

Gasman, Marybeth; Baez, Benjamin; and Turner, Caroline Sotello Viernes. 2008. Understanding Minority-Serving Institutions. New York: SUNY Press.

Hepburn, Mary A.; Niemi, Richard G.; and Chapman, Chris. September 2000. "Service Learning in College Political Science: Queries and Commentary". PS: Political Science and Politics 33:617-622.

Jones, Susan Robb; LePeau, Lucy A.; and Robbins, Claire K. March/April 2013. "Exploring the Possibilities and Limitations of Service-Learning: A Critical Analysis of College Student Narratives about HIV/AIDS.” The Journal of Higher Education 84:213-238.

Leonard, Stephen. T. December 1999. “'Pure Futility and Waste': Academic Political Science and Civic Education." PS: Political Science and Politics 32:749-754.

Mayhew, Matthew J. and Engberg, Mark E. January/February 2011. "Promoting the Development of Civic Responsibility: Infusing Service-Learning Practices in First-Year 'Success' Courses.” Journal of College Student Development 52:20-38.

Mitchell, Tania D.; Donahue, David M.; and Young-Law, Courtney. 2012. "Service Learning as a Pedagogy of Whiteness." Equity \& Excellence in Education 45:612-629.

Morgan, William and Streb, Matthew. March 2001. "Building Citizenship: How Student Voice in Service-Learning Develops Civic Values.”Social Sciences Quarterly 82:154-169.

Nishishiba, Masami; Nelson, Hal T.; and Shinn, Craig W. October 2005. "Explicating Factors that Foster Civic Engagement among Students". Journal of Public Affairs Education 11:269-285. 
Nuñez, Anne-Marie; Sparks, P. Johnelle; and Hernández, Eliza A. 2011. "Latino Access to Community Colleges and Hispanic-Serving Institutions: A National Study." Journal of Hispanic Higher Education 10:18-40.

Pike, Gary R. and Kuh, George D. May-June 2005. "First- and Second-Generation College Students: A Comparison of Their Engagement and Intellectual Development." The Journal of Higher Education 76:276-300.

Putnam, Robert D. 2001. Bowling Alone: The Collapse and Revival of American Community. USA: Simon \& Schuster Publishing.

Ryan, Sarah and Ream, Robert K. August 2016. "Variation Across Hispanic Immigrant Generations in Parent Social Capital, College-Aligned Actions, and Four-Year College Enrollments." American Educational Research Journal 53:953-986.

Sheil, Astrid and Rivera, José Luís. 2016. "Reaching Back Strategy: Using Mirroring, Trust, and Cultural Alignment in a Service-Learning Course to Impact Hispanic Parents' Assessment of College - A Case Study.” Journal of Latinos and Education 15:140-149.

Shetgiri, Rashmi; Kataoka, Sheryl H.; Ryan, Gery W.; Askew, Lawren Miller; Chung, Paul J.; and Schuster, Mark A. December 2009. "Risk and Resilience in Latinos: A Community-Based Participatory Research Study.” American Journal of Preventive Medicine 37:217-224.

Stoecker, Randy. 2016. Liberating Service Learning and the Rest of Higher Civic Engagement. Philadelphia: Temple University Press.

Stolley, Kathy Shepard; Collins, Takeyra; Clark, Patty; Hotaling, Diane E.; and Takacs, Robin Cote. September 2017. "Taking the Learning from Service Learning into the Postcollege World." Journal of Applied Social Science 11:109-126.

Sturgill, Amanda and Motley, Phillip. 2014. "Methods of Reflection about Service Learning: Guided vs. Free, Dialogic vs. Expressive, and Public vs. Private." Teaching \& Learning Inquiry: The ISSOTL Journal 2:81-93.

Terenzini, Patrick T.; Springer, Leonard; Yaeger, Patricia M.; Pascarella, Ernest T.; and Nora, Amaury. February 1996. "First-Generation College Students: Characteristics, Experiences, and Cognitive Development.” Research in Higher Education 37:1-22.

Vogelgesang, Lori J. and Astin, Alexander W. Fall 2000. "Comparing the Effects of Community Service and Service-Learning." Michigan Journal of Community Service Learning 7:25-34.

Waldner, Leora; Roberts, Kristie; Widener, Murray; and Sullivan, Brenda. Spring 2011. "Serving Up Justice: Fusing Service Learning and Social Equity in the Public Administration Classroom.” Journal of Public Affairs Education 17:209-232. 
Appendices for Service-Learning at an HSI

\section{Appendix A: Typology of Service-Learning Organizations}

Fall 2019

\begin{tabular}{|c|c|}
\hline Organization Type & $\begin{array}{c}\text { Number of Students (\% of } \\
\text { Students) }\end{array}$ \\
\hline Environment & $8(15.7 \%)$ \\
\hline Education and Advocacy & $19(37.3 \%)$ \\
\hline Community Services & $23(45.1 \%)$ \\
\hline Miscellaneous & $1(2.0 \%)$ \\
\hline Total & $\mathbf{5 1 ( 1 0 0 \% )}$ \\
\hline
\end{tabular}

Spring 2020

\begin{tabular}{|c|c|}
\hline Organization Type & $\begin{array}{c}\text { Number of Students (\% of } \\
\text { Students) }\end{array}$ \\
\hline Environment & $18(30.5 \%)$ \\
\hline Education and Advocacy & $13(22.0 \%)$ \\
\hline Community Services & $24(40.7 \%)$ \\
\hline Miscellaneous & $4(6.8 \%)$ \\
\hline Total & $\mathbf{5 9 ( 1 0 0 \% )}$ \\
\hline
\end{tabular}

Appendix B: Student Feedback on Service-Learning Project - Quantitative

Fall 2019

\begin{tabular}{|c|c|c|c|c|c|c|c|}
\hline Question & $\begin{array}{c}\# \\
\text { Responses }\end{array}$ & $\begin{array}{c}\text { "Strongly } \\
\text { Disagree" }\end{array}$ & "Disagree" & "Neutral & "Agree" & $\begin{array}{c}\text { "Strongly } \\
\text { Agree" }\end{array}$ & $\begin{array}{c}\text { Average } \\
\text { Score } \\
\text { (SD) }\end{array}$ \\
\hline $\begin{array}{c}\text { The service- } \\
\text { learning } \\
\text { project } \\
\text { improved } \\
\text { my } \\
\text { community } \\
\text { engagement } \\
\text { skills }\end{array}$ & 48 & $0(0 \%)$ & $2(4 \%)$ & $11(23 \%)$ & $14(29 \%)$ & $21(44 \%)$ & 4.13 \\
\hline $\begin{array}{c}\text { I felt as } \\
\text { though my } \\
\text { participation } \\
\text { in service- } \\
\text { learning } \\
\text { benefitted } \\
\text { my } \\
\text { community }\end{array}$ & 48 & $0(0 \%)$ & $0(0 \%)$ & $17(35 \%)$ & $10(21 \%)$ & $21(44 \%)$ & 4.08 \\
& & & & & & & \\
\hline
\end{tabular}


Spring 2020

\begin{tabular}{|c|c|c|c|c|c|c|c|}
\hline Question & $\begin{array}{c}\# \\
\text { Responses }\end{array}$ & $\begin{array}{l}\text { "Strongly } \\
\text { Disagree" }\end{array}$ & "Disagree" & "Neutral & "Agree" & $\begin{array}{l}\text { "Strongly } \\
\text { Agree" }\end{array}$ & $\begin{array}{c}\text { Average } \\
\text { Score } \\
\text { (SD) }\end{array}$ \\
\hline $\begin{array}{l}\text { The service- } \\
\text { learning } \\
\text { project } \\
\text { improved } \\
\text { my } \\
\text { community } \\
\text { engagement } \\
\text { skills }\end{array}$ & 37 & $0(0 \%)$ & $1(3 \%)$ & $6(16 \%)$ & $7(19 \%)$ & $23(62 \%)$ & $\begin{array}{c}4.38 \\
(0.94)\end{array}$ \\
\hline $\begin{array}{l}\text { I felt as } \\
\text { though my } \\
\text { participation } \\
\text { in service- } \\
\text { learning } \\
\text { benefitted } \\
\text { my } \\
\text { community }\end{array}$ & 37 & $0(0 \%)$ & $1(3 \%)$ & $4(11 \%)$ & $8(22 \%)$ & $24(65 \%)$ & $\begin{array}{c}4.49 \\
(0.79)\end{array}$ \\
\hline
\end{tabular}

Appendix C: Student Feedback on Service-Learning Project - Qualitative

Fall 2019

\begin{tabular}{|c|c|}
\hline Response Category & Number of Students \\
\hline Variety of Service Organizations & $6(15.8 \%)$ \\
\hline Engagement Zone Improvements & $4(10.5 \%)$ \\
\hline Organization Communication & $4(10.5 \%)$ \\
\hline Professor Feedback & $2(5.3 \%)$ \\
\hline Hours & $4(10.5 \%)$ \\
\hline Other & $6(15.8 \%)$ \\
\hline No Improvements Needed & $13(34.2 \%)$ \\
\hline Total Responses & $38(100 \%)$ \\
\hline
\end{tabular}

Spring 2020

\begin{tabular}{|c|c|}
\hline Response Category & Number of Students \\
\hline Variety of Service Organizations & $6(23 \%)$ \\
\hline Engagement Zone Improvements & $0(0 \%)$ \\
\hline Organization Communication & $0(0 \%)$ \\
\hline Professor Feedback & $0(0 \%)$ \\
\hline Hours & $2(8.7 \%)$ \\
\hline Other & $2(8.7 \%)$ \\
\hline No Improvements Needed & $13(56.8 \%)$ \\
\hline Total Responses & $23(100 \%)$ \\
\hline
\end{tabular}

